\title{
PEMANFAATAN VIDEO MENCUCI TANGAN DALAM MENINGKATKAN MOTIVASI DAN PRAKTIK MENCUCI TANGAN PADA ANAK USIA SEKOLAH DASAR
}

\author{
Rahmita Nuril Amalia \\ Staff Dosen Akademi Keperawatan "YKY” Yogyakarta \\ Email: rahmitanurilamalia@gmail.com, Hp: 081328805002
}

\begin{abstract}
ABSTRAK
Mencuci tangan merupakan kebiasaan yang dilakukan dengan tujuan untuk membersihkan kotoran yang melekat pada kulit tangan dengan menggunakan air bersih dan sabun. Program perilaku hidup bersih dengan mencuci tangan memakai sabun dilakukan di tatanan Sekolah Dasar untuk mengajari anak-anak tentang langkah mencuci tangan yang benar. Mengajarkan kebiasaan baik mencuci tangan kepada anak sebaiknya dilakukan sedini mungkin. Anak senang sekali mempelajari dan menyentuh segala sesuatu baik yang kotor atau tidak dan tanpa mencuci tangan. Akibatnya anak-anak dapat menderita penyakit. Mencuci tangan ada langkah-langkah yang harus dilakukan, World Health Organization (WHO) sebagai badan kesehatan dunia telah merekomendasikan tentang langkah-langkah mencuci tangan dengan sabun yang baik dan benar. Tujuan dari penelitian ini adalah mengetahui pemanfaatan video mencuci tangan dapat meningkatkan motivasi dan praktik mencuci tangan pada anak usia sekolah di Sekolah Dasar di Wilayah Puskesmas Kasihan II.

Design penelitian adalah penelitian kuantitatif dengan pendekatan pre dan post only test design. Analisis data menggunakan Uji Paired T Test dan Independen Test.

Hasil penelitian menunjukkan terdapat perbedaan motivasi dan kemampuan cuci tangan anak antara pretest dan postest pada kelompok intervensi dan kelompok kontrol. Terdapat perbedaan motivasi dan kemampuan cuci tangan anak sebelum dan setelah intervensi pada kelompok intervensi yang memanfaatkan media video mencuci tangan dibandingkan dengan kelompok kontrol yang menggunakan media poster.
\end{abstract}

Kata kunci : video, cuci tangan, anak usia sekolah

\section{PENDAHULUAN}

Mencuci tangan merupakan kebiasaan yang dilakukan dengan tujuan untuk membersihkan kotoran yang melekat pada kulit tangan dengan menggunakan air bersih dan sabun. Program perilaku hidup bersih dengan mencuci tangan memakai sabun dilakukan di tatanan Sekolah Dasar untuk mengajari anak-anak tentang langkah mencuci tangan yang benar.

Mengajarkan kebiasaan baik mencuci tangan kepada anak sebaiknya dilakukan sedini mungkin. Anak senang sekali mempelajari dan menyentuh segala sesuatu baik yang kotor atau tidak dan tanpa mencuci tangan. Akibatnya anak-anak dapat menderita penyakit. Menurut penelitian, penyakit pembunuh anak nomor 1 di Indonesia adalah karena diare, padahal hal ini dapat dicegah dengan mengajarkan anak untuk mencuci tangan.
Beberapa penyakit yang dapat disebabkan karena kurang pedulinya terhadap kegiatan cuci tangan pakai sabun, diantaranya: diare, infeksi saluran pernafasan, infeksi cacingan. Cara terbaik untuk mencegahnya adalah dengan membiasakan mencuci tangan dengan memakai sabun (Kamarudin, 2009 dalam Mirzal ).

Mencuci tangan adalah teknik yang sangat mendasar dalam mencegahdan mengendalikan infeksi, dengan mencuci tangan dapat menghilangkan sebagian besar mikroorganisme yang ada di kulit (Hidayat, 2005 dalam Mirzal). Masalah-masalah tersebut timbul karena kurangnya pengetahuan serta kesadaran akan pentingnya kesehatan terutama kebiasaan mencuci tangan. Cuci tangan merupakan cara murah dan efektif dalam pencegahan penyakit menular. Namun hingga saat ini kebiasaaan tersebut seringkali dianggap remeh (Sari, 2011). 
Berdasarkan kajian WHO cuci tangan menggunakan sabun dapat mengurangi angka kejadian diare sebesar 47\% (Darmiatun, 2008 dalam Sari). Mencuci tangan dengan sabun mengurangi infeksi saluran pernafasan yang berkaitan dengan pneumonia hingga lebih dari $50 \%$. Berbagai macam jenis penyakit yang dapat timbul terkait kebiasaan tidak cuci tangan yaitu diare, Infeksi Saluran Pernapasan, Flu Burung (H1N1), dancacingan (Depkes RI, 2010).

Dengan memberikan promosi melalui video tentang cuci tangan diharapkan penyakit menular tersebut bisa mengurangi risiko terjadinya penularan penyakit melalui tangan dengan mencuci bersih tangan. Penggunaan media video sebagai bentuk pengenalan gerakan mencuci tangan yang diberikan pada anak usia sekolah sebagai panduan melakukan mencuci tangan secara mandiri di rumah diharapkan dapat meningkatkan motivasi dan praktik mencuci tangan sehingga meningkatkan perilaku hidup bersih dan sehat.

Menurut Notoatmodjo (2010), pengetahuan adalah suatu hasil tahu dan ini terjadi setelah orang melakukan penginderaan terhadap suatu objek tertentu. Perilaku yang didasarkan pengetahuan akan lebih langgeng daripada perilaku yang tidak didasari oleh pengetahuan (Notoatmodjo, 2012). Beberapa hasil penelitian menunjukkan bahwa pengetahuan dapat mempengaruhi perilaku seseorang.

Kebiasaan mencuci tangan dilakukan ketika sebelum dan sesudah makan, selesai bermain dari luar, setelah membuang sampah, setelah dari kamar kecil, dan kegiatan lainnya yang memerlukan cuci tangan. Mencuci tangan ada langkah-langkah yang harus dilakukan, World Health Organization (WHO) sebagai badan kesehatan dunia telah merekomendasikan tentang langkah-langkah mencuci tangan dengan sabun yang baik dan benar.
Terdapat beberapa faktor yang berhubungan dengan kepatuhan pelaksanaan langkah-langkah mencuci tangan (hand hygiene). Menurut teori Lawrence Green ada tiga faktor utama yang mempengaruhi setiap individu dalam melakukan sebuah perilaku dalam hal ini perilaku hand hygiene yaitu faktor pendorong (predisposing factor), yang terwujud dalam pengetahuan, sikap, kepercayaan, nilai, persepsi. Faktor penguat (reinforcing factor) yang terwujud dalam supervisi, peran kader, tokoh agama, tokoh masyarakat. Faktor pemungkin (enabling factor), yang terwujud dalam sarana dan prasarana, sumber daya, kebijakan, pelatihan (Sutiyono dkk, 2014)

Teori lain terkait faktor yang mempengaruhi perilaku yang dikemukakan oleh Gibson dan Ivancevich yaitu faktor individu, faktor organisasi, dan faktor psikologi (Yanti dan Warsito, 2013). Adapun faktor psikologis terdiri dari persepsi, sikap, kepribadian, belajar dan motivasi (Purwanti, 2010).

Berdasar uraian di atas, maka rumusan masalah dalam penelitian ini adalah "Apakah pemanfaatan video mencuci tangan dapat meningkatkan motivasi dan praktik mencuci tangan pada anak usia sekolah di Sekolah Dasar di Wilayah Puskesmas Kasihan II?”.

\section{METODE PENELITIAN}

Rancangan penelitian ini adalah penelitian kuantitatif dengan pendekatan pre dan post only design. Lokasi penelitian ini akan dilaksanakan di wilayah kerja Puskesmas Kasihan II Yogyakarta, yaitu SD Padokan I untuk kelompok intervensi dan SD Padokan II untuk kelompok kontrol Subyek dalam penelitian ini adalah anak SD Kelas V di SD Padokan I dan SD Padokan II sejumlah 39 responden untuk tiap kelompok. Instrumen yang digunakan dalam penelitian ini adalah lembar observasi pelaksanaan cuci tangan dan penilaian motivasi. 


\section{HASIL PENELITIAN}

\section{Analisis Univariat}

Analisis univariat mencakup karakteristik anak usia sekolah dasar dilihat dari data demografi dalam kuesioner identitas partisipan dan disajikan dalam bentuk tabel distribusi frekuensi, setiap variabel yang diteliti. Analisis univariat ini dilakukan pada kelompok intervensi maupun kelompok kontrol dan dilakukan pada variabel perancu (confounding) yang menggambarkan karakteristik partisipan dan variabel terikat (dependen), seperti tercantum pada tabel 4.1.

Tabel 4.1. Distribusi frekuensi berdasarkan karakteristik partisipan pada kelompok intervensi dan kelompok kontrol SD Padokan 1 dan SD Padokan 2 tahun 2015 (n=60)

\begin{tabular}{|c|c|c|c|c|c|}
\hline \multirow[t]{2}{*}{ Karakteristik partisipan } & \multicolumn{2}{|c|}{$\begin{array}{l}\text { Kelompok } \\
\text { interrensi }\end{array}$} & \multicolumn{2}{|c|}{$\begin{array}{l}\text { Kelompok } \\
\text { kontrol }\end{array}$} & \multirow[t]{2}{*}{$p$} \\
\hline & 1 & y & 1 & $\%$ & \\
\hline \multicolumn{6}{|l|}{ t'sia } \\
\hline 10 tahun & 12 & 38,5 & 12 & 38,5 & 0,810 \\
\hline 11 tahun & 15 & 46.2 & 16 & 48,7 & \\
\hline 12 tabun & 3 & 15,4 & 2 & 128 & \\
\hline \multicolumn{6}{|l|}{ Gender } \\
\hline Laki-aki & 14 & 48,7 & 14 & 48,7 & 1000 \\
\hline Perempuan & 16 & 513 & 16 & 513 & \\
\hline
\end{tabular}

Tabel 4.1 menunjukkan bahwa kelompok usia partisipan terbanyak pada kelompok intervensi dan kelompok kontrol adalah berada pada usia 11 tahun. Gender terbanyak pada kelompok intervensi dan kelompok kontrol adalah perempuan. Berdasarkan tabel 4.1 dapat diketahui bahwa karakteristik partisipan berdasarkan usia dan gender mempunyai nilai $\mathrm{p}>0,05$ sehingga dapat disimpulkan bahwa karakteristik partisipan antara kelompok intervensi dan kelompok kontrol berdasarkan usia dan gender mempunyai varian yang sama (homogen).

\section{Analisis Bivariat}

Pengujian pemanfaatan video cuci tangan terhadap motivasi dan kemampuan cuci tangan anak sekolah dasar pada kelompok intervensi dan kelompok kontrol dilakukan untuk mengetahui perbedaan sebelum dan setelah dilakukan intervensi. Hasil uji normalitas untuk setiap variabel menunjukkan $p<0,05$ sehingga data dinyatakan tidak normal. Hasil analisis perbedaan motivasi dan kemampuan cuci tangan anak antara pretest dan posttest pemanfaatan video mencuci tangan pada kelompok intervensi dan kelompok kontrol tergambar dalam tabel 4.2.

Tabel 4.2 Perbedaan motivasi dan kemampuan cuci tangan pretest dan postest pada kelompok intervensi di SD Padokan I tahun $2018(n=30)$

\begin{tabular}{lcccc}
\hline \multicolumn{1}{c}{ Variabel } & $\mathrm{n}$ & $\begin{array}{c}\text { Mean } \\
(\mathrm{SD})\end{array}$ & $t$ & $p$ \\
\hline $\begin{array}{l}\text { Motivasi } \\
\begin{array}{l}\text { Pretest } \\
\text { Posttest }\end{array}\end{array}$ & 30 & $9,600(0,813)$ & $-2,065$ & 0,048 \\
$\begin{array}{l}\text { Kemampuan } \\
\text { cuci tangan }\end{array}$ & & $9,933(0,253)$ & & \\
$\begin{array}{l}\text { Pretest } \\
\text { Posttest }\end{array}$ & 30 & $5,033(1,033)$ & $-8,305$ & 0,000 \\
& & $6,800(0,406)$ & & \\
\hline
\end{tabular}

Berdasarkan tabel 4.2 diketahui bahwa rata-rata motivasi kelompok intevensi pada saat pretest adalah 9,600 dengan standar deviasi 0,813 , sedangkan pada postest adalah 9,933 dengan standar deviasi 0,253. Uji Paired T Test menunjukkan bahwa $p 0,048<0,05$ yang berarti bahwa ada perbedaan motivasi sebelum dan setelah intervensi pada kelompok intervensi. Rata-rata kemampuan cuci tangan pre test pada kelompok intervensi adalah 5,033, dengan standar deviasi 1,033, sedangkan rata-rata kemampuan cuci tangan post test kelompok intervensi adalah 6,800, dengan standar deviasi 0,406. Uji Paired $T$ Test menunjukkan bahwa $p 0,00<0,05$ yang berarti bahwa ada perbedaan kemampuan mencuci tangan sebelum dan setelah intervensi pada kelompok intervensi. 
Tabel 4.3 Perbedaan motivasi dan kemampuan cuci tangan pretest dan postest pada kelompok kontrol di SD Padokan II tahun 2018 (n=30)

\begin{tabular}{|c|c|c|c|c|}
\hline Variabel & $\mathrm{n}$ & $\begin{array}{c}\text { Mean } \\
(\mathrm{SD})\end{array}$ & $t$ & $p$ \\
\hline Motivasi & \multirow{4}{*}{30} & & \multirow{4}{*}{0,183} & \multirow{4}{*}{0,856} \\
\hline Pretest & & $9,733(0,739)$ & & \\
\hline Posttest & & $9,700(0,702)$ & & \\
\hline $\begin{array}{l}\text { Kemampuan } \\
\text { cuci tangan }\end{array}$ & & & & \\
\hline Pretest & \multirow[t]{2}{*}{30} & $5,033(1,033)$ & \multirow[t]{2}{*}{$-5,267$} & \multirow[t]{2}{*}{0,000} \\
\hline Posttest & & $6,500(0,973)$ & & \\
\hline
\end{tabular}

Berdasarkan tabel 4.3 diketahui bahwa rata-rata motivasi kelompok kontrol pada saat pretest adalah 9,733 dengan standar deviasi 0,739, sedangkan pada postest adalah 9,700 dengan standar deviasi 0,702. Uji Paired T Test menunjukkan bahwa $p 0,856>0,05$ yang berarti bahwa tidak ada perbedaan motivasi sebelum dan setelah intervensi pada kelompok kontrol. Rata-rata kemampuan cuci tangan pre test pada kelompok kontrol adalah 5,033, dengan standar deviasi 1,033, sedangkan rata-rata kemampuan cuci tangan post test kelompok kontrol adalah 6,500, dengan standar deviasi 0,973. Uji Paired T Test menunjukkan bahwa $p 0,00<0,05$ yang berarti bahwa ada perbedaan kemampuan mencuci tangan sebelum dan setelah intervensi pada kelompok intervensi.

Tabel 4.4 Perbedaan motivasi dan kemampuan cuci tangan pretest dan postest pada kelompok intervensi dan kelompok kontrol di SD Padokan

\section{I \& II tahun $2018(\mathrm{n}=60)$}

\begin{tabular}{llllll} 
& \multicolumn{2}{c}{$\begin{array}{c}\text { Kelompok } \\
\text { Intervensi } \\
(\mathrm{n}=30)\end{array}$} & $\begin{array}{c}\text { Kelompok } \\
\text { Kontrol } \\
(\mathrm{n}=30)\end{array}$ & & \\
\cline { 2 - 4 } Variabel Test & $p$ \\
& \multicolumn{1}{c}{$\begin{array}{c}\text { Mean } \\
(\mathrm{SD})\end{array}$} & $\begin{array}{c}\text { Mean } \\
(\mathrm{SD})\end{array}$ & & \\
\hline Motivasi & 9,933 & 9,700 & $-1,712$ & 0,001 \\
& $(0,253)$ & $(0,702)$ & & \\
Cuci & 6,800 & 6,500 & $-1,557$ & 0,005 \\
tangan & $(0,406)$ & $(0,973)$ & & \\
\hline
\end{tabular}

Berdasarkan tabel 4.4 menunjukkan bahwa selisih motivasi pretest dan posttest pada kelompok intervensi mengalami peningkatan sebesar 9,933. Sedangkan selisih motivasi pretest dan posttest pada kelompok kontrol mengalami peningkatan yaitu sebesar 9,700. Hasil uji Independen T test diketahui bahwa terdapat perbedaan motivasi antara kelompok intervensi dengan kelompok kontrol dimana nilai $\mathrm{p}=0,001$.

Selisih kemampuan mencuci tangan pretest dan postest pada kelompok intervensi antara mengalami peningkatan sebesar 6,800 . Sedangkan selisih kemampuan mencuci tangan pretest dan posttest pada kelompok kontrol antara mengalami penurunan yaitu sebesar 6,500. Hasil uji Independen $T$ test diketahui bahwa terdapat perbedaan kemampuan cuci tangan antara kelompok intervensi dengan kelompok kontrol dimana nilai $\mathrm{p}=0,005$

\section{PEMBAHASAN}

\section{Karakteristik Partisipan}

Pada penelitian ini karakteristik partisipan pada kelompok intervensi dan kelompok kontrol berdasarkan usia yang terbanyak adalah kelompok usia 11 tahun yaitu sebanyak 46,2\%. Menurut Mubarak (2007), salah satu faktor yang dapat mempengaruhi pengetahuan seseorang adalah pengalaman. Pengalaman merupakan sesuatu yang pernah dialami seseorang dan mungkin akan menambah sesuatu. Dalam penelitian ini, perbedaan usia tidak terpaut jauh, sehingga setiap partisipan memiliki daya tangkap dan pola pikir yang hampir sama dan tidak mempengaruhi perbedaan tingkat pengetahuan dan sikap partisipan.

Distribusi frekuensi jenis kelamin dalam penelitian ini terbagi merata antara laki-laki yaitu sebanyak 48,7\% dan perempuan sebanyak 51,3\%. Perbedaan jenis kelamin tidak mempengaruhi tingkat pengetahuan dan sikap partisipan secara signifikan setelah diberikan pendidikan kesehatan. Meskipun terdapat perbedaan perhatian yang diberikan partisipan saat penyuluhan, dimana 
partisipan perempuan lebih memberikan perhatian dibanding partisipan laki-laki. Namun dalam penelitian ini perbedaan jenis kelamin tidak mempengaruhi tingkat pengetahuan dan sikap partisipan.

\section{Pemanfaatan Video Cuci Tangan dalam Meningkatkan Motivasi dan Kemampuan Cuci Tangan}

Uji statistik kelompok intervensi dan kelompok kontrol pada penelitian ini terlebih dahulu dilakukan uji normalitas data. Menurut uji normalitas, sebaran data pada kelompok intervensi dan kelompok kontrol berdistribusidi normal, sehingga uji statistik yang digunakan selanjutnya adalah Uji Paired T Test untuk menganalisis motivasi dan kemampuan mencuci tangan anak pretest dan posttest pada kelompok intervensi dan kelompok kontrol, Uji Independen $T$ Test digunakan untuk menganalisis perbedaan penurunan pretest dan postest antara kelompok intervensi dengan kelompok kontrol.

Berdasarkan uji tersebut, menunjukkan bahwa pemanfaatan video mencuci tangan memberikan pengaruh terhadap peningkatan motivasi dan kemampuan cuci tangan anak. Hal ini ditunjukkan dalam tabel 4.2 dengan adanya perbedaan rerata motivasi pretest dan posttest pada kelompok intervensi $(\mathrm{p}=0,048)$ dan perbedaan rerata kemampuan mencuci tangan pretest dan posttest pada kelompok intervensi $(\mathrm{p}=0,000)$. Perbedaan rerata motivasi pretest dan posttest pada kelompok kontrol $(\mathrm{p}=0,856)$ dan perbedaan rerata kemampuan mencuci tangan pretest dan posttest pada kelompok kontrol $(\mathrm{p}=0,000)$.

Motivasi dan kemampuan mencuci tangan anak pada kelompok intervensi mengalami perubahan rerata yang signifikan, akan tetapi pada tabel 4.4 ditunjukkan bahwa intervensi dengan poster tidak berpengaruh signifikan terhadap peningkatan motivasi anak pada kelompok kontrol.
Berbeda dengan pemanfaatan video mencuci tangan dapat memberikan perbedaan signifikan sebelum dan setelah intervensi baik pada kelompok intervensi maupun kelompok kontrol.

Proses pemberian pendidikan kesehatan memerlukan suatu media yang menarik untuk mempengaruhi pemahaman dan mengubah perilaku kelompok sasaran (Setyowati,2011). Berbagai media dapat digunakan dalam melakukan pendidikan kesehatan mencuci tangan, diantaranya adalah media manusia/ceramah/audio, media cetak/visual, media audio visual, dan media komputer/interaktif/peraga. Media cetak memiliki kecenderungan tidak memberi pengaruh terhadap peningkatan pengetahuan dan sikap sasaran. Hal ini sejalan dengan penelitian Khairani (2009) yang menyebutkan bahwa media cetak berupa leaflet cenderung tidak sistematis, tidak terarah, tidak rinci, dan tidak lengkap selain itu tidak mampu menimbulkan perhatian, kesadaran, serta pemahaman dalam melakukan cuci tangan pada anak SD.

Penggunaan media audiovisual (video) mempunyai tingkat pengaruh yang tinggi dalam menstimulasi indera pendengaran dan penglihatan pada saat penyampaian materi pendidikan kesehatan (Setyowati, 2011). Hal ini sesuai dengan penelitian Albert et al (2007), Ramsay, et al. (2012), Krawczyk, et al (2012) yang menyebutkan bahwa pendidikan kesehatan melalui video mampu menyampaikan pesan yang konsisten dan memberi kesempatan kepada penonton untuk menonton berulang kali dan dapat meningkatkan pemahaman.

Media audiovisual dapat menampilkan ketrampilan dan menunjukkan situasi yang nyata. Media audiovisual dengan penyampaian dan tampilan persuasif sangat bermanfaat dalam meningkatkan pengetahuan dan perilaku hidup sehat (Setyowati, 2011). Media video dan animasi mampu meningkatkan keinginan dan 
motivasi anak untuk belajar secara lebih baik bila dibandingkan dengan media tertulis.

Hasil ini selaras dengan penelitian yang dilakukan oleh Fadilla (2014) bahwa ada peningkatan ketrampilan cuci tangan pada siswa sekolah dasar setelah diberikan penyuluhan kesehatan menggunakan video dengan ratarata presentase responden setelah dilakukan penyuluhan sebanyak $85,29-100 \%$.

\section{SIMPULAN}

Berdasarkan hasil penelitian terhadap 60 partisipan dan uraian dalam pembahasan, dapat diambil beberapa kesimpulan sebagai berikut:

1. Terdapat pengaruh pemanfaatan video mencuci tangan terhadap motivasi dan kemampuan cuci tangan pada anak sekolah.

2. Karakteristik partisipan berdasarkan usia paling banyak adalah usia 11 tahun dengan presentase $46,2 \%$ sedangkan berdasarkan jenis kelamin semiliki jumlah yg seimbang untuk laki-laki maupun perempuan.

3. Ada perbedaan motivasi dan kemampuan cuci tangan anak antara pretest dengan posttest pada kelompok intervensi

4. Ada perbedaan motivasi dan kemampuan cuci tangan anak antara pretest dengan posttest pada kelompok kontrol

5. Ada perbedaan motivasi dan kemampuan cuci tangan anak sebelum dan setelah intervensi pada kelompok intervensi yang memanfaatkan video mencuci tangan dan kelompok kontrol yang memanfaatkan media poster.

\section{DAFTAR PUSTAKA}

Arikunto, S. (2010). Prosedur Penelitian Suatu Pendekatan Praktik. Jakarta: Rineka Cipta.
Dahlan, S. M. (2013). Statistika untuk Kedokteran dan Kesehatan: Deskriptif, Bivariat, dan Multivariat: Dilengkapi Aplikasi Menggunakan SPSS (5th ed.). Jakarta: Salemba Medika.

Cheppy Riyana. 2007. Pedoman Pengembangan Media Video. Jakarta: P3AI UPI.

Cunningham, F.G., dkk. 2006. Obstetri Williams. Jakarta : EGC

Daryanto. 2010. Media Pembelajaran. Yogyakarta: Gava Media.

Dimyati, Mudjiono.2002. Belajar dan Pembelajaran. Jakarta : Rineka Cipta.

Dinas Kesehatan Kabupaten Bantul. 2014. Profil Kesehatan Kabupaten Bantul 2014.

Djemari Mardapi. 2008. Teknik Penyusunan Instrumen Tes dan Non Tes. Jakarta: Mitra Cendekia Press.

Fadilla, N. H. (2014). Pengaruh Penyuluhan Cuci Tangan Menggunakan Media Video terhadap Ketrampilan Pada Siswa Sekolah Dasar Fitriani. (2013). Penerapan Media Audio Visual dan Small Group Discussion untuk meningkatkan keefektifan dalam pembelajaran IPA Biologi materi bumi dan langit pada siswa kelas $\mathrm{X}$ program keahlian akomodasi perhotelan 1 SMK Negeri 4 Surakarta tahun 2012/2013

Imam, G. (2013). Aplikasi Analisis Multivariat dengan Program IBM SPSS 21. Semarang: Badan Penerbit Universitas Dipenogoro.

Jumiarni, dkk, 1995, Asuhan Keperawatan Perinatal, EGC, Jakarta.

Notoatmodjo, Soekidjo. 2003. Pendidikan Dan Perilaku Kesehatan. Rineka Cipta. Jakarta.

Hidayat, A. A. (2002). Pengantar Pendidikan Keperawatan. Jakarta: Sagung Seto.

Nasir, A., Muhith, A., \& M.E.Ideputri. (2011). Buku Ajar : Metodologi Penelitiana 
